\section{A Date with McLean}

On Thursday, May 29, the Honourable Walter McLean, Minister of State (Immigration) will represent the Government of Canada as keynote speaker during the Symposium Refuge or Asylum: A Choice for Canada? His topic will be the refugee claims process in Canada. As Minister of State for Immigration, Mr. McLean has responsibility for policy formulation and operations. Refugee determination has been a particular concern in recent months.

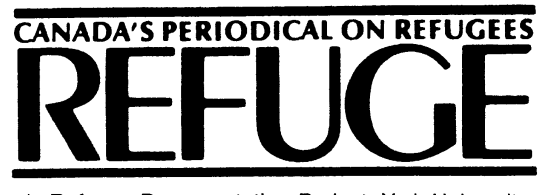

c/o Refugee Documentation Project, York University 4700 Keele Street, North York, Ontario M3J 1P3

\section{Editor:}

Howard Adelman

Feature Editors:

Tanya Basok and Alex Zisman

Managing Editor:

Leslie Rider

Refuge is dedicated to encouraging assistance to refugees, by providing a forum for sharing information and opinion on Canadian and international issues pertaining to refugees. It is published four times a year by the Refugee Documentation Project. It is a non-profit, independent periodical supported by private donations and by subscriptions. It is a forum for discussion, and the views expressed do not necessarily reflect those of its funders or staff.

All material in Refuge may be reproduced without permission unless copyrighted or otherwise indicated. Credit should be given to the author or source if named.

Subscription rates for one year are $\$ 20.00$. Please enclose payment with your order. No discounts can be given for American funds because of bank charges for foreign cheques.

\section{Logo design:}

Dreadnaught Cooperative Inc., Toronto

Second Class Mail Registration No. 5512 ISSN 0229-5113

\title{
About the Main Estimates 1986-87 The Government's Expenditure Plan
}

\author{
Dan Heap, M.P., Spadina \\ (edited version)
}

The Standing Committee on Labour, Employment and Immigration will be discussing the 1986-87 Budget at a meeting in May 1986. The total budget for the Employment and Immigration Department will be $\$ 4,729$ million; $\$ 130$ million will be allocated to the Immigration Programme. The amount represents a decrease of $5.4 \%$ over the $1985-86$ budget forecast of $\$ 138,001$ million.

The government intends to reduce the Adjustment Assistance Programme which provides living expenses to indigent refugees and their dependants. The Programme will receive $\$ 29.7$ million, a decrease of $\$ 7.6$ million $(25.6 \%)$ over 1985 .

The Immigrant Settlement and Adaptation Programme's budget will remain unchanged at \$3.64 million. Funding for the Government's Host Programme for Refugee Resettlement, which is still a pilot project, will remain at $\$ 500,000$. The budget for the Refugee Status Advisory Committee will also be reduced from $\$ 1.745$ million for $1985-86$ to $\$ 1.6$ million for $1986-87$.

The Immigration Appeal Board will receive $\$ 4.667$ million, an increase of $6.4 \%$ over 1985-86. Because of increased personnel costs, the government is saying the IAB needs a bigger budget, particularly as the Board will have to deal now with redetermination of refugee claims.

I feel that the over-all decrease in the Immigration Programme's budget shows a rejection of Canada's commitment to the refugee movement and the plight of those refugee claimants now living in Canada. It also seems that the government is bent on implementing the recommendations of the Neilson Task Force Report to admit only those refugees capable of being supported by private sponsors.

\section{About the Fifth and Sixth Report}

\section{Dan Heap, M.P., Spadina (edited version)}

Last Friday, April 18, 1986, the Minister of State for Immigration, the Honourable Walter McLean, should have tabled the Government's Response to the Standing Committee on Employment \& Immigration's Reports on Refugee Determination in Canada and the Backlog.

Instead of doing so, the Minister gave a letter to the Clerk of the House of Commons which said that the Government needed more time to consider various alternatives before making a final decision on the reports. This is the second time the Minister has breached Standing Order 99 (2) which states that "a comprehensive report" must be submitted to Parliament within 120 days.

I have asked Mr. Bosley, the Speaker of the House, to review Mr. McLean's breach of parliamentary procedure through the Committee on Elections, Privileges and
Procedure and am now awaiting a response from the Speaker.

I fear that the Government may be deliberately creating delay again, and then just prior to Parliament's summer recess submit a legislative package; if the opposition immigration critics do not immediately agree, we will then be accused of preventing the government from helping refugee claimants.

For example, if the Government proposes a determination system with a completely unsatisfactory appeal, we would wish, with many members of the public, to support an amendment. However a debate would eat up time, and the Government would argue that we must hurry up before Parliament rises at the end of June.

It is important that refugee claimants and their supporters are aware of what is happening. 